\title{
Professional Esports Players are not Obese: Analysis of Body Composition Based on Years of Experience
}

\author{
Los Jugadores Profesionales de Esports no son Obesos: Análisis \\ de la Composición Corporal Basada en los Años de Experiencia
}

Frano Giakoni-Ramírez¹; Daniel Duclos-Bastías² \& Rodrigo Yáñez-Sepúlveda ${ }^{3}$

\begin{abstract}
GIAKONI-RAMÍREZ, F.; DUCLOS-BASTÍAS, D. \& YÁÑEZ-SEPÚLVEDA, R. Professional esports players are not obese: Analysis of body composition based on years of experience. Int. J. Morphol., 39(4):1081-1087, 2021.

SUMMARY: Esports are considered a form of electronic sports that have become an important element of popular culture. Its evolution and continuous development have led to consider esports as a profession, increasing the number of players, practice modalities and hours of play dedicated to this field. Therefore, scientific and economic contributions have increased in recent years, however, there is little research on body composition in this group of players. To describe the anthropometric characteristics and body composition in professional esports players according to the years of experience. The sample consisted of 53 esports players competing in the Spanish professional league, with a mean age of $21.01 \pm 0.39$ years, whose body composition was measured by electrical bioimpedance with the TANITA ${ }^{\circledR}$ BC-601F Segment device. No differences were found between groups nor significant associations according to linear regression $(p<0.05)$ between body composition variables and years of experience as a professional player. The years of practice, as well as the esports practiced have no influence on the body composition of professional esports players.
\end{abstract}

KEY WORDS: Electronic Sports; Body composition; E-athletes.

\section{INTRODUCTION}

Esports are considered as a form of sport that has had a great development in recent years (Hamari \& Sjöblom, 2017; Kane \& Spradley, 2017; Jenny et al., 2017), it has seen an increase in the number of people who perform them and the interest in competitive esports is growing (Lindberg et al., 2020), its main characteristic is based on the practice facilitated by electronic systems, another factor to consider is that in this discipline athletes compete connected to the internet in different locations around the world (Bayrakdar et al., 2020). From an organizational point of view, the competition systems are regulated worldwide (Bayrakdar et al.; Jenny et al., 2017) and competitions are broadcast globally thanks to the media, promoting the games and players involved (Martorell Castellano \& Rom Rodríguez, 2011). Therefore, esports have gradually become a thriving business, thus constituting an important element of popular culture product of its reach. Its diffusion and popularity has increased, even in groups outside the video game sector itself (Gómez \& Navarro, 2013). This has led to the emergence of a potential market with great potential for development (Gómez, 2007) and that by 2020 reached a value of more than MMU\$1,000, with an estimated annual growth of $15.7 \%$ (Newzoo, 2020).

Scientific and economic contributions on this sector have increased, coming to consider the practice of video games as a profession (Kopp, 2017). The introduction of the payment of salaries to players and the presence of sponsorships in the teams has led to the increase of professional players (Taylor, 2012), increasing the demand and the number of annual competitions that capture the attention of new spectators (Karakus, 2015). This fact has forced the design, construction and remodeling of new facilities that can host the organization of international esports events (Baltezarevic \& Baltezarevic, 2018; Jenny et al., 2018).

The presence of rules, competitions and training, among other aspects, leads authors such as Chae \& Kang

\footnotetext{
${ }^{1}$ Facultad de Educación, Universidad Autónoma de Chile, Chile.

${ }^{2}$ Escuela Educación Física, Pontificia Universidad Católica de Valparaíso, Chile.

${ }^{3}$ Escuela de Educación. Pedagogía en Educación Física, Universidad Viña del Mar, Chile.
} 
(2011) to consider esports as a new sport. However, this practice has major differences with respect to traditional sport such as: 1) the esports practice is performed in a reduced space; 2) it is mainly performed in sedentary behavior; 3) players most of the time remain physically isolated for hours; and 4) it favors the development of sedentary and unhealthy lifestyles (Williams et al., 2008; Kopp; Baltezarevic \& Baltezarevic). This is why sedentary behavior seems an inherent element of esports practice as players remain virtually immobile for long periods of time. However, Jiménez \& Araya (2012) concluded that video games can become promoters of a healthy lifestyle, thus combating sedentary lifestyles and obesity. In addition, this practice does not always exert a negative social and psychological influence since it is related to an improvement in motor learning and tenacity to face reallife situations (Jiménez \& Araya; Castañer et al., 2016). Esports, as well as traditional sport, have a different physical (Sánchez et al., 2019) and psychological (Montero Herrera \& Carazo Vargas, 2019) implication so authors such as Pérez-Rubio et al. (2017) associate this practice to the previously mentioned negative behaviors.

The potential hazards faced by esports athletes are similar to the hazards found in many sports, recreational and work environments, including musculoskeletal, ergonomic, biological and psychosocial hazards. The esports athlete's posture in a gaming chair, prolonged screen exposure and hundreds of repetitive movements during gaming sessions are contributing factors to the development of these hazards, to this we add that the average professional esports athlete spends 5,5 to 10 hours gaming daily (Emara et al., 2020), a considerable amount of daily life. Although esports are not a moderate to vigorous intensity activity, there are factors related to the level of physical activity and body composition that can condition the quality of training and decrease the risk of injuries especially spine and musculoskeletal pain, another aspect to consider is that esports are considered sedentary in nature due to the lack of body movement, but they can impose significant demands on the body due to rapid and continuous finger movements and concentration demands promoting physical and psychological stress (Hamari \& Sjöblom), in addition it is common to find a high level of back pain and injuries due to the large amount of time players spend in repetitive positions. A recent study revealed that Eathletes with musculoskeletal pain participated in fewer esports workouts compared to those without pain, suggesting a potentially negative effect of pain on esports participation (Lindberg et al.), this variable could condition the quality of workouts and performance in high competition, generating a negative effect associated with low muscle mass and increased adipose tissue.
First of all, it is relevant to analyze that several studies have shown that body composition is a determining variable in physical performance at any age, both in sport and in other activities (González-Neira et al., 2015; Castañer et al.; Jakse et al., 2021) a factor that conditions the quality of training, since having a low level of muscle tissue could generate a deficit of strength and muscle power increasing the risk of injury, due to this, having optimal levels of muscle could delay or inhibit the onset of musculoskeletal pain and injuries (Wang et al., 2006), this would give the possibility of training sessions of longer duration and quality. On the other hand, body fat is necessary due to its energetic and regulatory function, among others, but an excessively low or high level of this variable is related to health and performance impairments (González-Neira et al.), the increase of adipose tissue could increase the levels of proinflammatory cytokines that are associated with chronic systemic inflammation, this inflammatory process induces chronic immune activation, functional impairment of immune cells and decreased immunity, in this sense obesity and associated inflammation lead to several debilitating chronic diseases (Frasca et al., 2021), which can condition the appearance of muscle pain, thus decreasing performance. Therefore, to reduce the risk of injury and optimize performance in esports, it is necessary to enhance muscle development and nutritional quality, which has an impact on an optimal body composition profile to withstand the demands of sport (Emara et al.). For this reason, the assessment of body composition takes on special relevance since players with high levels of body fat and low levels of fat-free mass may have a higher risk of injury and low quality of training, in addition to the systematic evaluation allows us to identify differences between the most experienced players with those who are just starting at the competitive level in this discipline. In this aspect, among one of the valid procedures to assess body composition is electrical bioimpedance, which is a non-invasive and easy to apply double in-direct method (Leirós-Rodríguez et al., 2017, 2018). Through the measurement of resistance to the flow of different electrical currents in different body regions, it provides information on muscle mass, fat mass, intra and extracellular water distribution, among other variables (Lafargue et al., 2013; García-Soidán et al., 2014).

Despite the information available on the influence of esports on sedentary behaviors, few studies have analyzed the influence of esports-induced behaviors on the body composition of players. Therefore, the aim of the present study was to determine the influence of years of practice on the body composition of professional esports players. 


\section{MATERIAL AND METHOD}

Ethical considerations. The research participants agreed to participate voluntarily and signed an informed consent prior to data collection, in which they were informed of the objectives of the study, as well as the conditions under which the measurements would be carried out and the confidentiality of the information obtained, for which the results were coded with numbers and letters to mask the identity of the players. For the development of the research, the guidelines established in the Declaration of Helsinki for human studies were considered to safeguard the integrity of the participants (World Medical Association, 2015).

Participants. The sample consisted of professional esports players $(n=53)$ with an average age of $21.01 \pm 0.39$ years belonging to different teams in Spain, who voluntarily agreed to participate in the research. At the time of the fieldwork, the players were competing on a regular basis in the Gamergy esports event in Madrid (Spain) organized by the Liga de Videojuegos Profesional (LVP) in 2018. The players who participated in the sample were competing in the esports modalities League of Legends (LOL), Counter Strike Global Offensive (CSGO), Call of Duty (COD), Hearthstone, FIFA, Clash Royale (CR), Fortnite and Rocket League (RL).

The selection of players was carried out by consecutive non probabilistic sampling, selecting all possible subjects to whom we had access who met the inclusion criteria, these being: 1) not having ingested water or food in the previous four hours; 2) not having performed strenuous exercise in the previous twelve hours; 3) not wearing metallic instruments (watches, rings, bracelets, prostheses or metallic implants) at the time of measurement; and 4) being a professional gamer with a current contract. Their characteristics are shown in Table I.

Instruments. The Tanita BC-601F Segment scale (Tanita, Japan) with an accuracy of $0.1 \mathrm{~kg}$ was used to collect data on the body composition of the esports players. A 1,0 mm accurate Soehnle measuring rod (Soehnle, Germany) fixed vertically to the wall was used to obtain height data.

The values collected with the Tanita BC-601F Segment scale were stored in a matrix of the Microsoft Excel computer program in which values corresponding to the following variables were also included: gender, age (years), height $(\mathrm{m})$, weight $(\mathrm{kg})$, body fat $(\%)$, fat-free mass $(\mathrm{kg})$, bone mass $(\mathrm{kg})$, BMI $\left(\mathrm{kg} / \mathrm{m}^{2}\right)$, metabolic age (years), body water (\%), visceral fat, sports experience (years), sports modality practiced and the team of which they were a member at that time.

Procedure. Prior to the start of data collection, the measuring instruments were checked and calibrated. For the calibration of the Tanita BC-601F Segment scale, one kilogram calibration weights were used. The measuring rod was calibrated using a tape measure, checking the proper functioning of the braking system.

Before starting the body composition measurements of the players by bioimpedance, the participating players filled out the informed consent form, and then proceeded with the measurement of height and information on age, years of experience in esports or team of origin, the players then took off all the metallic materials they were wearing, as well as their shoes, to be measured in the measuring rod to establish their size.

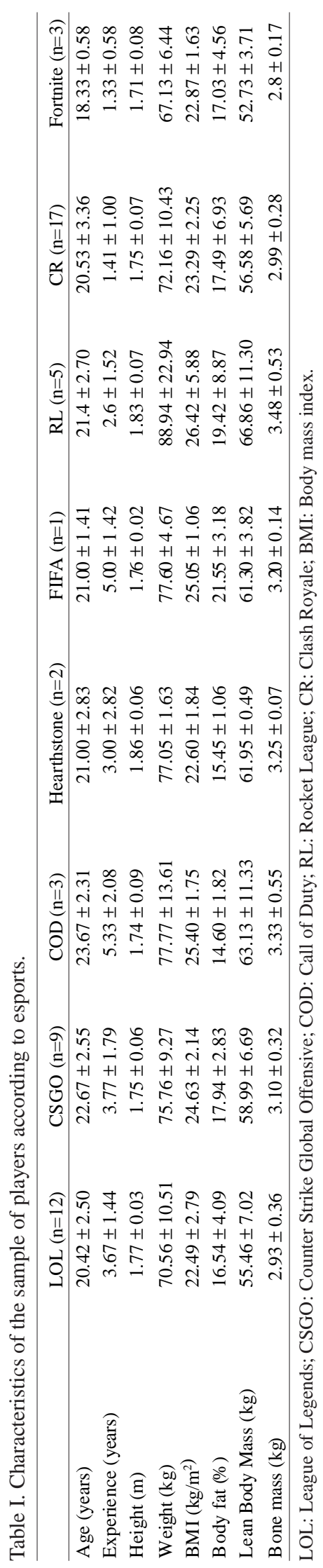

1083 
Once the size was obtained, the players underwent an electrical bioimpedance test. For this, the indications of Alvero et al. (2011) about the necessary requirements for valid and reliable measurements were followed. The subjects removed their socks, in case they had not done so previously, to facilitate the conduction of electric current to the body through two electrodes located at the base of the platform. Once the feet were placed on the electrodes of the scale, the players were provided with the manual measurement system, which had two more electrodes. Once the measurement data were obtained, the body composition information was included in the Excel matrix in which the previously collected data were stored.

It should be noted that the field work was carried out over two days, making it possible to gather the esports players who met the necessary conditions to be included as subjects in the study.

Data Analysis. The distribution of the data was initially assessed using the Kolmogorov-Smirnov normality test. Since the data collected had a normal distribution, a statistical analysis was performed based on parametric tests. To obtain descriptive results, central tendency statistics were obtained: mean, standard deviation and confidence intervals. For the analysis of comparison of means according to grouping variables: years of experience, weight, body fat, muscle mass, bone mass, BMI, body water and visceral fat, the ANOVA test was applied. Subsequently, a multiple linear regression test was performed using the Pearson correlation coefficient. The magnitude of the correlation effect was based on the following scale: trivial $(<0.10)$, small $(0.10-0.29)$, moderate $(0.30-0.49)$, high $(0.50-0.69)$, very high $(0.70-0.89)$, almost perfect $(\geq 0.90)$, and perfect $(\mathrm{r}=1.00)$ following the guidelines of Hopkins $e t$ al. (2009), the R2 (R-squared) and R2a (adjusted R-squared) values were also used and the model considered the F-test to evaluate the explanatory capacity of the athletes' experience (independent) on the variation of the body composition variables (dependent). Each body composition variable was analyzed according to the subjects' years of experience. A value of $p<0.05$ was established to determine statistical significance. Statistical analysis was performed using the SPSS statistical package from the manufacturer IBM® (v. 25.0; SPSS Inc., IL).

\section{RESULTS}

Table II shows the values of the descriptive statistics for the body composition values according to the years of esports experience, as well as the results of the ANOVA test for the sample of esports players. It should be noted that there were no significant differences between the variables under study as a function of years of sporting experience $(\mathrm{p}<0.05)$.

Figure 1 shows the body composition profile of all the players $(\mathrm{n}=53)$ considered in the study. Values such as height $(\mathrm{m})$, weight $(\mathrm{kg})$, fat mass (\%), fat-free mass ( $\mathrm{kg}$ ), bone mass $(\mathrm{kg}), \mathrm{BMI}\left(\right.$ weight $/$ height $^{2}$ ) and total body water (\%) can be visualized

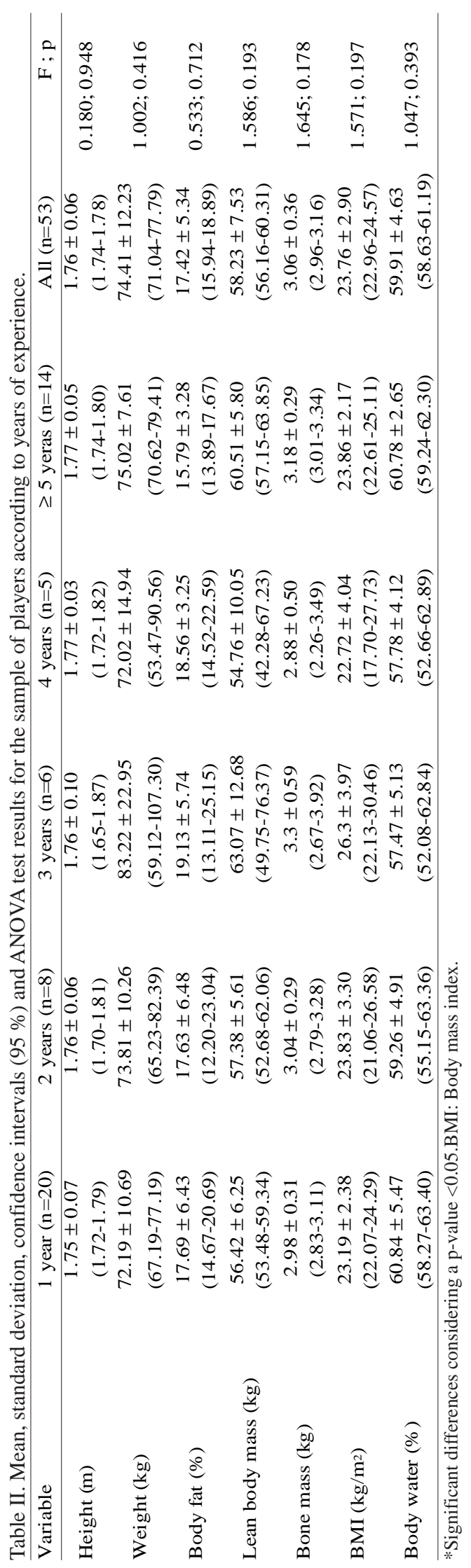




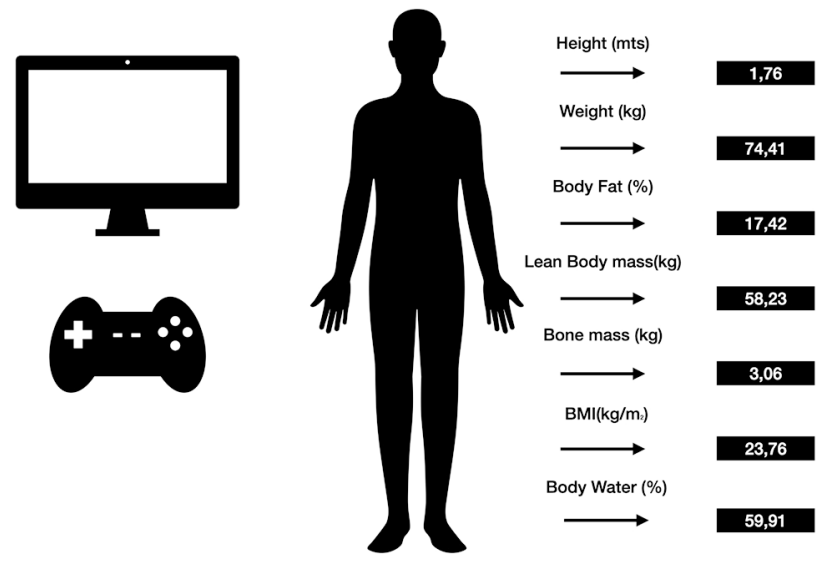

Fig 1. Representation of the body composition profile of the group of professional esports players.
Table III presents the results obtained from the linear regression analysis of the body composition variables based on the model according to the years of experience in esports practice by the professional players in the sample. A small correlation $(0.10-0.29)$ is not significant in the variables height $(\mathrm{m})$, body fat $(\%)$, fatfree mass $(\mathrm{kg})$ and bone mass $(\mathrm{kg})$, while the variables weight $(\mathrm{kg})$, BMI $\left(\mathrm{kg} / \mathrm{m}^{2}\right)$ and body water $(\%)$ present a trivial correlation $(>0,10)$. In relation to the values, there is no association between the level of experience and the body composition variables analyzed according to years of experience $(\mathrm{p}<0.05)$.

Table III. Linear regression analysis of body composition variables based on model according to years of experience.

\begin{tabular}{lccccc}
\hline Variable & $\mathrm{R}$ & $\mathrm{R}$ square & $95 \%$ confidence interval & $\mathrm{F}$ & $\mathrm{p}$ value \\
\hline Height $(\mathrm{m})$ & 0.119 & 0.014 & $1.71-1.78$ & 0.733 & 0.396 \\
Weight $(\mathrm{kg})$ & 0.093 & 0.009 & $66.03-79.09$ & 0.444 & 0.508 \\
BMI $\left(\mathrm{kg} / \mathrm{m}^{2}\right)$ & 0.081 & 0.007 & $21.83-24.94$ & 0.334 & 0.566 \\
Body fat $(\%)$ & 0.113 & 0.013 & $15.55-21.25$ & 0.656 & 0.422 \\
Lean body mass $(\mathrm{kg})$ & 0.191 & 0.037 & $51.91-59.83$ & 1.96 & 0.167 \\
Bone mass $(\mathrm{kg})$ & 0.045 & 0.036 & $3.75-3.14$ & 1.921 & 0.172 \\
Body water $(\%)$ & 0.045 & 0.002 & $57.77-62.74$ & 0.101 & 0.747 \\
\hline
\end{tabular}

*Significant association considering a p-value $<0,05$

\section{DISCUSSION}

The main results of our study show normal values of body fat and fat-free mass in the group of e-athletes, the values of BMI, total body water are within the range of healthy people or athletes. First, it is important to note that the study allows to identify a profile in esports and to identify differences according to years of experience in body composition, this allows to go in line with what suggested by Nagorsky \& Wiemeyer (2020) regarding the importance of the discovery of possible deficits regarding physical training related to the health of esports players (Rudolf, 2020). The results showed that the esports analyzed do not have more overweight and/or obese players with respect to players with normal weight, this in the same line of the findings of DiFrancisco-Donoghue et al. (2020) where they identify significant differences between in relation to college esports players and other sports, finding a higher level of fat mass and lower mineral content in esports athletes in comparison with other sports, also in this same study they point out that the body mass index is not an accurate measure of the health of esports players. If we compare the main results obtained in that study with the present study we can visualize that fat mass by DEXA in esports was $24.0 \pm 6.7$
$\%$, in sportsmen it was $19.1 \pm 6 \%(\mathrm{p}=0.05)$, while in our study according to BIA it was $17.42 \pm 5.34 \%$, as for fat free mass in esports values were found to be $50.8 \pm 4.0 \mathrm{~kg}$, in esports it was $59.8 \pm 8.5 \mathrm{~kg}(\mathrm{p}=0.003)$ and in our study according to BIA $58.23 \pm 7.53$. Finally, the bone mineral content based on DEXA was $2.9 \pm 0.3 \mathrm{~kg}$ in sportsmen and $3.2 \pm 0.4 \mathrm{~kg}(\mathrm{p}=0.03)$ in athletes, while in our study based on BIA the values were $3.06 \pm 0.36 \mathrm{~kg}$ respectively. These results corroborate those provided by Jiménez \& Araya on the promotion of healthy lifestyles through the practice of esports, thus combating sedentary lifestyles and obesity. Regarding body composition in this discipline, no differences have been found between players who participate in video games that include movement and those who are more sedentary in nature (Bochner et al., 2015).

Regarding the years of esports experience, in the present study it was found that there are no significant differences in body composition values as a function of years of practice. In line with this finding, Bochner et al. concluded that there were no modifications in the body composition of players who participated in esports that included movement. 
After analyzing the results of the present investigation, it can be added that there are no modifications in body composition over time in esports that do not include moderate to vigorous physical activity, in contrast to the results obtained in the study conducted by Bayrakdar et al. with an international sample of esports players, where they concluded that BMI increased as the level of physical activity decreased and the daily hours of esports increase. This is an important factor to consider in new lines of research.

On the other hand, González-Neira et al. stated that body composition is a determinant variable in sports performance in soccer. Considering that the study sample was composed of the best players in Spain in their corresponding esports modality and attending to the results analyzed, it should be noted that body composition does not directly influence the performance of esports players, since physical involvement is reduced, but it could do so indirectly due to the psychological improvements and the lower risk of suffering health deterioration, along the same lines as the findings found by Roncone et al. (2020), where they concluded from a sample of university esports players that a higher level of physical activity would predict greater mental strength. Finally, it is important to consider that the body composition profile affects the quality of training and the risk of injury in this sport and should be considered within the evaluation process in this discipline. Finally, the importance of awareness and management of common musculoskeletal and health hazards, opportunities for health promotion and recommendations for performance optimization should be emphasized (Emara et al.).

\section{CONCLUSIONS}

To conclude, this study shows that the years of sports practice, as well as the esports practiced have no influence on the body composition of professional players. Despite this, it should be considered that in this sport cognitive and fine motor variables play a fundamental role in performance and decision making, an important factor to consider in improvement programs. Finally, this research shows that BIA can be a good method to classify, monitor and optimize body composition in esports.

\section{ACKNOWLEDGMENTS}

To UCAM Esports Club and Catholic University of Murcia, for the support and assistance provided for this research.
GIAKONI-RAMÍREZ, F; DUCLOS-BASTÍAS, D. \& YÁÑEZSEPÚLVEDA, R. Los jugadores profesionales de esports no son obesos: análisis de la composición corporal basada en los años de experiencia. Int. J. Morphol., 39(4):1081-1087, 2021.

RESUMEN: Los esports, son considerados como una forma de deporte electrónico que se han convertido en un importante elemento de la cultura popular. Su evolución y continuo desarrollo han llevado a considerar los esports como una profesión, incrementando el número de jugadores, modalidades de práctica y horas de juego dedicadas a este ámbito. Es por esto que las aportaciones científicas y económicas han se han incrementado en los últimos años, sin embargo, existe un escaso desarrollo de investigaciones sobre la composición corporal en este grupo de jugadores. El objetivo de este estudio fue describir las características antropométricas y la composición corporal en jugadores profesionales de esports según los años de experiencia. La muestra estuvo compuesta por 53 jugadores de esports que compiten en la liga profesional española, con una edad media de 21,01 \pm 0,39 años a los que se midió la composición corporal mediante bioimpedancia eléctrica con el dispositivo TANITA® BC-601F Segment. No se encontraron diferencias entre los grupos ni asociaciones significativas según regresión lineal $(\mathrm{p}<0,05)$ entre las variables de composición corporal y los años de experiencia como jugador profesional. Los años de práctica, así como el esports practicado no tienen influencia sobre la composición corporal de los jugadores profesionales de esports.

PALABRAS CLAVE: Deportes Electrónicos; Composición Corporal; E-atletas.

\section{REFERENCES}

Alvero, J. R.; Gómez, L.; Ronconi, M.; Fernández, R. \& Porta, J. Bioelectrical impedance analysis as a method of body composition estimation: A practical approach. Rev. Andal. Med. Deporte, 4(4):167-74, 2011.

Baltezarevic, R. \& Baltezarevic, B. The impact of video games on the formation of eSports. Phys. Educ. Sport, 6(1):137-47,2018.

Bayrakdar, A.; Yıldız, Y.\& Bayraktar, I. Do e-athletes move? A study on physical activity level and body composition in elite e-sports. Phys. Educ. Stud. Creat. Spec., 24(5):259-64, 2020.

Bochner, R.; Sorensen, K. \& Belamarich, P. The impact of active video gaming on weight in youth: A meta-analyisis. Clin. Pediatr., 54(7):620$8,2015$.

Castañer, M.; Camerino, O.; Landry, P. \& Parés, N. Quality of physical activity of children in exergames: Sequential body movement analysis and its implications for interaction design. Int. J. Hum. Comput. Stud., 96:6778, 2016.

Chae, H. \& Kang, S. An exploratory research on categorizing e-sports as one of the sports. J. Korea Game Soc., 11(3):85-95, 2011.

DiFrancisco-Donoghue, J.; Werner, W.; Douris, P. \& Zwibel, H. Esports players, got muscle? Competitive video game players' physical activity, body fat, bone mineral content, and muscle mass in comparison to matched controls. J. Sport Health Sci., 2020. DOI: https://www.doi.org/ 10.1016/j.jshs.2020.07.006

Emara, A.; Cruickshank, J.; Kampert, M.; Piuzzi, N.; Schaffer, J. \& King, D. Gamer's health guide: optimizing performance, recognizing hazards, and promoting wellness in esports. Curr. Sports Med. Rep., 19(12):537-45, 2020 
Frasca, D.; Reidy, L.; Cray, C.; Diaz, A.; Romero, M. Kahl, K. \& Blomberg, B. B. Influence of obesity on serum levels of SARS-CoV-2-specific antibodies in COVID-19 patients. PLoS One, 16(3):e0245424, 2021.

García-Soidán, J. L.; López, J.; Ogando, H.; Fernández, A.; Padrón, A. \& Prieto, J. Utilidad de la cineantropometría y la bioimpedancia para orientar la composición corporal y los hábitos de los futbolistas. Retos Nuevas Tend. Educ. Fis. Deporte Recreac., (25):117-9, 2014.

Gómez, S. \& Navarro, N. Videojuegos e información. Una aproximación a los news games españoles como nueva óptima informativa. Rev. Icono, 11(2):31-52, 2013.

Gómez, S. Videojuegos: el desafío de un nuevo medio a la comunicación social. Hist. Comun. Soc., 12:71-82, 2007.

González-Neira, M.; Mauro-Martín, I.; García-Angulo, B.; Fajardo, D \&. Garicano-Vilar, E. Valoración nutricional, evaluación de la composición corporal y su relación con el rendimiento deportivo en un equipo de fútbol femenino. Span. J. Hum. Nutr. Diet., 19(1):36-48, 2015.

Hamari, J. \& Sjöblom, M. What is a eSports and why do people watch it? Internet Res., 27(2):211-32, 2017.

Hopkins, W.; Marshall, S.; Batterham, A. \& Hanin, J. Progressive statistics for studies in sports medicine and exercise science. Med. Sci. Sports Exerc., 41(1):3-1, 2009.

Jakse B.; Jakse, B.; Cuk I. \& Sajber D. Body Composition, Training Volume/Pattern and Injury Status of Slovenian Adolescent Female High-Performance Gymnasts. Int. J. Environ. Res. Public Health, 18(4):2019, 2021.

Jenny, S. E.; Keiper, M.; Taylor, B. J.; Williams, D. P.; Gawrysiak, J.; Manning, R. D.; Tutka, P. M. eSports Venues. J. Appl. Sport Manag., 10(1), 2018.

Jenny, S. E.; Manning, R.; Keiper, M. \& Olrich, T. Virtual(ly) athletes: where eSports fit within the definition of "sport". Quest, 69(1):1-18, 2017.

Jiménez, J. \& Araya, Y. The effect of playing videogames on social, psychological and physiological variables in children and adolescents. Retos Nuevas Tend. Educ. Fis. Deporte Recreac., (21):43-9, 2012.

Kane, D. \& Spradley, B. Recognizing Esports as a sport. Sport J., 20:1-9, 2017.

Karakus, C. Comparing Traditional Sports and Electronic Sports. Doctoral Thesis. Champaign (IL), University of Illinois, 2015.

Kopp, J. Ejes para una investigación en deportes electrónicos. Juegos Juguetes Dispos. Tecnol., 6(11), 2017.

Lafargue, L.; Bergues, L.; Verdecia, M.; Laurencio, Y. \& Ortega, Y. Parámetros bioeléctricos in vitro e in vivo, estimados con los

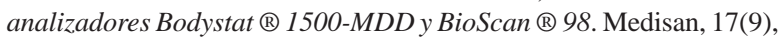
2013.

Leirós-Rodríguez, R.; Romo-Pérez, V.; Arce-Fariña, M. E. \& GarcíaSoidán, J. L. Relación entre la composición cor-poral y movimientos producidos durante la marcha en personas mayores. Rev. Fisioter., 39(3):101-7, 2017.

Leirós-Rodríguez, R.; Romo-Pérez, V.; Arce-Fariña, M. E. \& GarcíaSoidán, J. L. Associations between body composition and movements during gait in women. Rev. Int. Med. Cienc. Activ. Fis. Deporte, 18(72):693-707, 2018.

Lindberg, L.; Nielsen, S.; Damgaard, M.; Sloth, O.; Rathleff, M. \& Straszek, C. Musculoskeletal pain is common in competitive gaming: a cross-sectional study among Danish esports athletes. BMJ Open Sport Exerc. Med., 6(1):000799, 2020.

Martorell Castellano, C. \& Rom Rodríguez, J. A. La cara oculta de los advergames. La explotación crítica de un nuevo recurso de la publicidad. Questiones Public. Rev. Int. Comun. Public., 1(16):24-39, 2011.

Montero Herrera, B. \& Carazo Vargas, P. Benefits of Mental Practice in Sport Practice. Apunts Educ. Fis. Deportes, (135):82-99, 2019.

Nagorsky, E. \& Wiemeyer, J. The structure of performance and training in esports. PLoS One, 15(8):e0237584, 2020.

Newzoo. Global Esports Market Report 2020, Light Version. Amsterdam, The Netherlands, 2020.
Pérez-Rubio, C.; González, J. \& Garcés de los Fayos, E. Personalidad y burnout en jugadores profesionales de e-sports. Cuad. Psicol. Deporte, 17(1):41-50, 2017.

Roncone, J.; Kornspan, A.; Hayden, E. \& Fay, M. The Relationship of Physical Activity and Mental Toughness in Collegiate Esports Varsity Student-Athletes. Ohio Assoc. Health Phys. Educ. Recreat. Dance, 41(1):31-40, 2020.

Rudolf, K.; Bickmann, P.; Froböse, I.; Tholl, C.; Wechsler, K. \& Grieben, C. Demographics and health behavior of video game and eSports players in Germany: the eSports study 2019. Environ. Res. Public Health, 17(6):1870, 2020.

Sánchez, M.; Hernández, D.; Carretero, M. \& Sánchez-Sánchez, J. Level of Opposition on Physical Performance and Technical-Tactical Behaviour of Young Football Players. Apunts Educ. Fis. Deportes, 137:71-84, 2019.

Taylor, T. L. Raising the Stakes: E-Sports and the professionalization of Computer Gaming. London, The MIT Press, 2012.

Wang, H.; Chen, C.; Shiang, T.; Jan, M. \& Lin, K. Riskfactor analysis of high school basketball-player ankle injuries: A prospective controlled cohort study evaluating postural sway, ankle strength, and flexibility. Arch. Phys. Med. Rehabil., 87(6):821-5, 2006.

Williams, D.; Yee, N. \& Caplan, S. Who plays, how much, and why? Debunking the stereotypical gamer profile. J. Comp. Mediat. Commun. Monogr., 13(4):993-1018, 2008.

World Medical Association. World Medical Association Declaration of Helsinki Ethical Principles for Medical Research Involving Human Subjects. Clin. Rev. Edu., 310(20):2191-4, 2015.

Corresponding autor:

Rodrigo Yáñez-Sepúlveda

Escuela de Educación

Pedagogía en Educación Física

Universidad Viña del Mar

Campus Rodelillo

Agua Santa 7055

Viña del Mar

CHILE

E-mail: rodrigo.yanez@uvm.cl

Received: 22-04-2021

Accepted: 22-05-2021 